\title{
Causes of the different behaviour of the shoreline on beaches with similar characteristics. Study case of the San Juan and Guardamar del Segura beaches, Spain
}

\author{
J.I. Pagán, M. López, I. López, A.J. Tenza-Abril, L. Aragonés* \\ Dept. of Civil Engineering, University of Alicante, Carretera San Vicent del Raspeig s/n, 03690 Alicante, Spain
}

\section{A R T I C L E I N F O}

\section{Article history:}

Received 7 March 2018

Received in revised form 4 April 2018

Accepted 4 April 2018

Available online xxx

Editor: D. Barcelo

\section{Keywords}

Shoreline evolution

Sand beach

Sand mineralogy

Sand morphology

\begin{abstract}
A B S T R A C T
Storms can alter the beach shape, relocating large volumes of sediments and generating drastic changes in the coastline. In the last 60 years, beaches shoreline behaviour has been different even though the energy of the waves was similar. Therefore, it is necessary to understand the factors that affect the sandy coasts for better future management. In this research, two beaches, with different erosion rate, located in the southeast of Spain (separated by only $40 \mathrm{~km}$ of distance) have been studied. The beaches: i) have similar orientations, ii) are open to waves with similar sand lengths of $9.8 \mathrm{~km}$ and $6.6 \mathrm{~km}$, and iii) have similar median sediment size $\left(\mathrm{D}_{50}\right)$.

For its study, shoreline evolution has been analysed from 1956 to 2017 . From the results obtained, it can be seen that: i) Between 1992 and 2017, San Juan just lost 3\% of its surface, while in the previous period (1956-1990) it was 50\%, and ii) Guardamar surface lost in 1992-2017 was 18\%, and in the previous period it was $14 \%$. For the analysis of the agents involved in both beaches, cross-shore profiles (volume), marine climate, biocenosis and sedimentology studies were carried out. The results showed that the energy on both beaches was very similar. The biocenosis had not changed and, however, the morphology of Guardamar seabed had increased to $1 \mathrm{~m}$ deep in some places, which had caused part of the beach berm erosion. Furthermore, important differences were found from the sedimentological study, concluding that the content of calcites and the degree of homogeneity of the particles are the real factors that caused these two beaches to behave differently against erosion.
\end{abstract}

\section{Introduction}

Throughout the world, coastal areas are highly productive. However, they are threatened by erosion, anthropogenic activities, etc. (EEA EropeanEnvironmentalAgency, 2006), since there are areas in which the population tends to concentrate, as they are favourable for the development for human activities, which increases the potential for anthropogenic and natural damage (Ballesteros et al., 2018). A consequence of this human activity is the increasing construction of channels, or the rivers regulation, which have altered the natural dynamics of the coasts as a result of sediment retention or the lack of erosion of river basins, which have generated erosion problems around the world (Anthony et al., 2014; De Leo et al., 2017; Syvitski et al., 2009; Syvitski and Saito, 2007). Coastal erosion is therefore becoming a problem of increasing intensity (Marchand, 2010).

The increasing use of the coastal zone makes it necessary to understand coastal processes and the evolution of the shoreline. Only in Europe, it is estimated that around $20,000 \mathrm{~km}$ of coastline, accounting for $20 \%$ of its entire length, has coastal erosion problems (EC EuropeanCommission, 2004). These areas are particularly vulnerable to both human-induced change and the effects of global warming (Nováčková and Tol, 2018). In this context, it is essential to have a thorough knowledge of the factors and processes involved in

\footnotetext{
* Corresponding author.

Email address: laragones@ua.es (L. Aragonés)
}

the coastal geomorphological system (Kumar et al., 2006), as well as to investigate strategies for mitigating and/or adapting to global erosion problems (Anthony, 2015; Syvitski et al., 2005), and the future consequences of sea level rise (Payo et al., 2016; Spencer et al., 2016).

The factors that influence the functioning of a beach are of different nature: on the one hand, there are the parameters that depend on the anthropogenic action that exists in the area, (Aragonés et al., 2015; Aragonés et al., 2016a; Pagán et al., 2016) and on the other hand, natural factors such as morphology, mineralogical composition of sediments or the maritime climate (López et al., 2016a; López et al., 2016b; Marcomini and López, 1997; Roberts et al., 1998).

One of the natural factors is grain size, a fundamental property of sediment particles, which affects their dragging, transport and deposition. Therefore, grain size analysis provides important clues for sediment source, transport history and deposition conditions (Bui et al., 1989; Guillén and Hoekstra, 1996). It is also important to know the characteristics of the material used in beach nourishment, since every time a modification of the natural sediment is made, there are a change in the sedimentology of the beaches (Marcomini and López, 1997; Pagán et al., 2018). The successive constructions carried out on the coastline have altered coastal dynamics (Newton et al., 2012; Pagán et al., 2017), producing an irregular cross-shore distribution in the sediments size (Bayram et al., 2001). Many authors such as Demarest and Kraft (1987) relate the movements of the shoreline to the movement of sediments above the off-shore depth. On-shore, the 
sediment particles are relocated within the cross-shore profile, while those that exceed the depth of closure (DoC) will not return to the beach (Aragonés et al., 2017b; Hallermeier, 1978; Hallermeier, 1980). However, others authors such as López et al. (2016a) demonstrate that the movement of the shoreline is due (among others) to the sediments wear, which experience at least three different erosion phenomena. These phenomena are: i) collision of suspended particles, causing a process of wear and sediment reduction; ii) dissolution of the carbonate fraction of the sample; and iii) rupture and separation between the mineral fraction and the carbonate fraction that initially formed the sediment. These three phenomena, which act together, lead to an alteration in the composition of the sand, and a decrease in the particle size with its corresponding cross-shore movement seaward. Another factor to be taken into account is the fragile union that conforms the particles, which makes it rapidly diminish the particle size, and consequently a retreat of the shoreline is produced (Pagán et al., 2018).

The maritime climate is another aspect that influences the shoreline evolution. Depending on the amount of energy released when the waves break, there are alterations of greater or lesser magnitude on any coastal sector. However, the magnitude and speed of change for a given wave energy will depend on the type of material on which it is produced (Pardo and Sanjaume, 2001).

The various natural factors mentioned above cause the shoreline to be in continuous movement. Emery (1961) developed a beach profiling methodology to measure short-term shore position changes over a 13-month period. However, in order to study the long-term historical evolution of the shoreline, it is necessary to have access to numerous databases, basically maps and historical nautical charts, in most cases with very limited reliability, and aerial photographs (Fenster et al., 1993). The latter provide greater and more reliable results, but their application is restricted to the last decades, making aerial photography the most used document for the calculation of erosion and/or accretion rates (Baily and Nowell, 1996; Jiménez et al., 1997; Ojeda et al., 2013). The use of aerial photographs taken in different years allows a quantitative comparison of the evolution of the shoreline in different areas. This allows establishing numerical trends, to estimate sedimentary movements or to evaluate the consequences of human actions (Anders and Byrness, 1991). In recent years, this technique has been perfected using digitally restored orthorecapitalized frames, which considerably reduces possible errors caused by the displacement of stereoscopic images (Moore and Griggs, 2002; Ojeda et al., 2002).

The study of the evolution of the shoreline is useful to establish a record of shoreline fluctuations and understand how the beach evolves and responds to environmental conditions (Norcross et al., 2002). However, there may be anthropogenic factors that modify the cross-shore profile of the beach by modifying its volume and not its surface, which can lead to significant errors in controlling the evolution of the shoreline from surfaces obtained from orthophotos. For that reason, in this work, both surface variations and the volume lost on the beach are analysed, in order to find out why two beaches with similar orientations, the same size of sediment and energy, present different shoreline evolution.

\section{Study area}

The present work focuses on two beaches located in the southeast of Spain, on the Mediterranean coast. These beaches are: i) the beach of San Juan-Muchavista located about $7 \mathrm{~km}$ northwest of the city of Alicante. It is a sandy beach that exceeds $100 \mathrm{~m}$ wide in several points, and whose total length is $6.6 \mathrm{~km}$. It is located between Cabo de las Huertas (Alicante) to the south and Cabo Azul (Campello) to the north, maintaining a north-south orientation.
San Juan beach has a total length of $6582 \mathrm{~m}$ and an average width of $80 \mathrm{~m}$, reaching a maximum of $130 \mathrm{~m}$. Its total area is $53.3 \mathrm{ha}$. It is an open beach with grey sand, and its median sediment size is $0.24 \mathrm{~mm}$ (average of 10 samples taken in 2014 by the University of Alicante). A massive regeneration was carried out on this beach between 1990 and 1991 with $4.284 .324 \mathrm{~m}^{3}$ of sand from Sierra Helada.

ii) The other study beaches are Viveros, Babilonia Centro, La Roqueta, Moncayo, El Campo and Les Ortigues, all located in the municipality of Guardamar del Segura, in the southeast of the province of Alicante. It borders at its northern end with the mouth of the Segura River, and limits to the south with the Canal de la Mata. This beach has a length of $9.9 \mathrm{~km}$ and an average width of $59 \mathrm{~m}$, reaching a maximum of $121 \mathrm{~m}$. Its total area is $23.4 \mathrm{ha}$. It is an open beach with golden sand, and its median sediment size is $0.271 \mathrm{~mm}$ ( 21 samples analysed by the University of Alicante). The actions carried out on this beach can be seen in Table 1.

In the area studied, tides have little relevance, with oscillations due to atmospheric pressure being even more important than tides themselves, with the value of astronomical tides being around $0.3 \mathrm{~m}$, whereas meteorological tides can reach values of up to $0.45 \mathrm{~m}$ (http:// www.puertos.es, and (Ecolevante, 2006)) (Fig. 1).

\section{Methodology}

For the study of the behaviour of the beaches, the following process was followed: i) study of the shoreline evolution; ii) analysis of the cross-shore profile (volume); iii) study of the maritime climate; iv) study of biocenosis; and v) sedimentological study (accelerated particle wear, X-ray diffraction and scanning electron microscopy).

\subsection{Shoreline evolution}

In order to obtain an analysis of the behaviour of the coastline before and after the different anthropogenic actions, the method described by Pagán et al. (2016); Pagán et al. (2017) was used. From the vectorization of the shoreline from aerial images (1956, 1977, 1981, $1986,1990,1992,1994,1996,1998$ ) or orthophotos (years 2000, 2002, 2005, 2007, 2009, 2012, 2014 and 2017) the shoreline evolution was obtained. For a better analysis and interpretation of the data, the periods were divided into time intervals 1956-1990 and 1992-2017. These periods were chosen due to the fact that on both beaches anthropic actions were carried out between the years 1990-1991. In Guardamar, breakwaters of the mouth of the Segura River were constructed, which cut off the longitudinal transport of sediments (Pagán et al., 2017), and $250,000 \mathrm{~m}^{3}$ were dumped on the beaches of Viveros and Centro. During the same period, San Juan beach was nourished with $>4.2$ million $\mathrm{m}^{3}$ of sand, which meant an increase in the beach surface area of $375,000 \mathrm{~m}^{2}$, and a change in the type of sediment.

Table 1

Summary of the actions carried out on the study beaches.

\begin{tabular}{|c|c|c|c|c|}
\hline \multirow[t]{2}{*}{ Period } & \multicolumn{2}{|l|}{ Guardamar } & \multicolumn{2}{|c|}{ San Juan/Muchavista } \\
\hline & Action & Consequence & Action & Consequence \\
\hline 1986-1992 & $\begin{array}{l}\text { Canalization of } \\
\text { the Segura } \\
\text { River }\end{array}$ & $\begin{array}{l}\text { Sediment } \\
\text { longitudinal } \\
\text { transport cut }\end{array}$ & - & - \\
\hline 1990-1992 & $\begin{array}{l}\text { Dumping of } \\
250,000 \mathrm{~m}^{3} \text { in } \\
\text { Viveros and } \\
\text { Centro }\end{array}$ & $\begin{array}{l}\text { Increase of } \\
15,000 \mathrm{~m}^{2} \text { in Centro } \\
\text { beach and } \\
14,000 \mathrm{~m}^{2} \text { in } \\
\text { Viveros }\end{array}$ & $\begin{array}{l}\text { Dumping of } \\
4,284,324 \mathrm{~m}^{3} \\
\text { of sand }\end{array}$ & $\begin{array}{l}\text { Increase of } \\
374,918 \mathrm{~m}^{2} \\
\text { of surface }\end{array}$ \\
\hline 1996-1998 & $\begin{array}{l}\text { Construction of } \\
\text { the marina of } \\
\text { Guardamar }\end{array}$ & $\begin{array}{l}\text { Retention of } \\
\text { sediments in its } \\
\text { interior }\end{array}$ & - & - \\
\hline
\end{tabular}




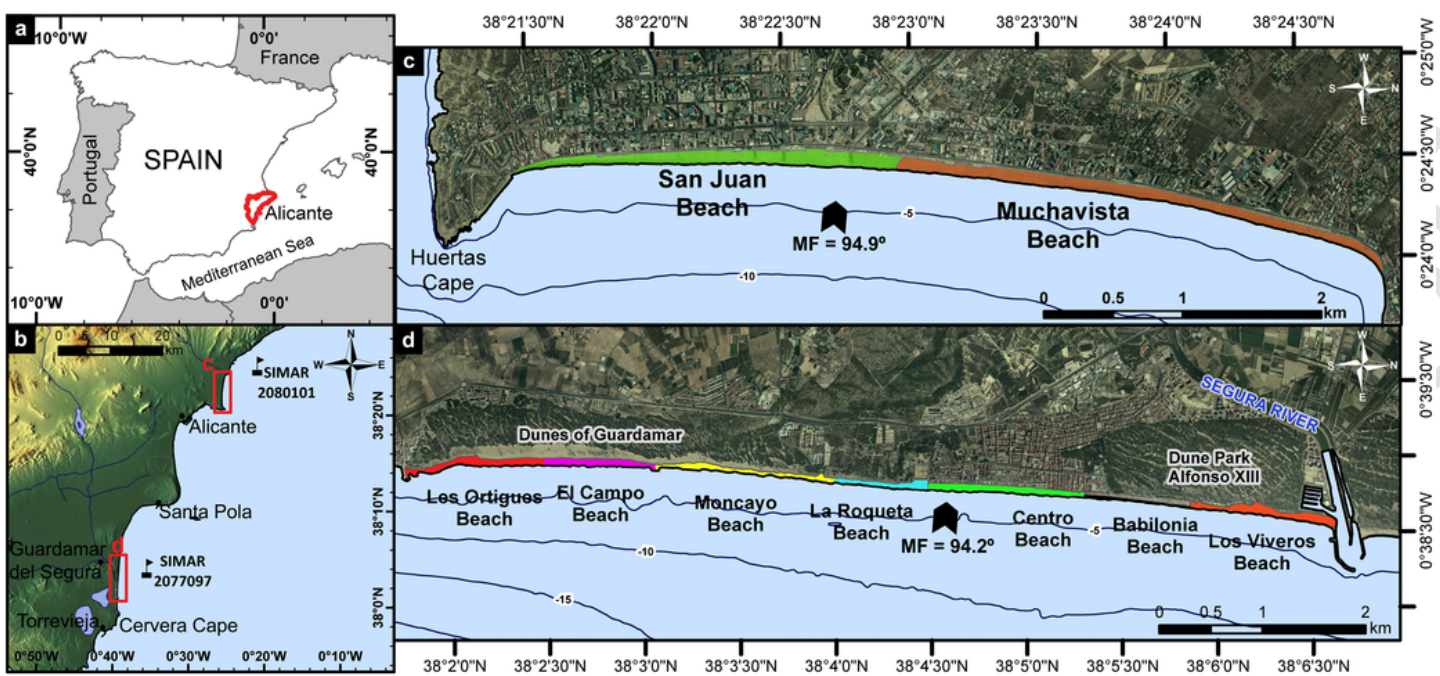

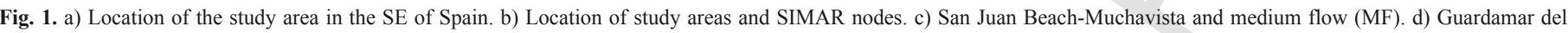
Segura beach and medium flow (MF).

\subsection{Cross-shore profile (volumes)}

For cross-shore profiling, a GPS system with GNSS correction in RTK (Real Time Kinematic) was used. The kinematic survey in real time consists of obtaining coordinates with centimetre precision. The use of the icverva.icv.gva.es network as a real-time active geodesic GNSS network provides the connection for real-time positioning with $2 \mathrm{~mm} \pm 1 \mathrm{ppm}$ accuracy on XYZ, in the UTM ETRS 89 time zone $30 \mathrm{~N}$ coordinate system. The field support work was carried out in a campaign that lasted from November 2006 to July 2017.

\subsection{Maritime climate}

Wave data $\left(\mathrm{H}_{\max }\right.$ (maximum height) and $\mathrm{H}_{\mathrm{s}, 12}$ (height exceeded $12 \mathrm{~h}$ per year), the period $(\mathrm{T})$, direction and probability of occurrence) were obtained from the SIMAR data from Puertos del Estado. In this case, the method chosen was that described by Pagán et al. (2017). These data are obtained from numerical models with data from 59 years of wind (1958-2017), being one of the most complete databases in the Mediterranean Sea (Infantes et al., 2009).

On the other hand, in order to obtain the depth of closure or lower limit of the equilibrium profile (DoC), the methodology described by Aragonés et al. (2017b) was used. DoC is obtained from the change in the trend of the median sediment size $\left(D_{50}\right)$ in the cross-shore profile, and IDW interpolation tool. The objective of obtaining the DoC is to study the usual movement of sediments in the cross-shore profile. Sedimentological data needed to obtain the DoC and morphological data were obtained from the Provincial Coastal Service of Alicante (Public Organism).

\subsection{Study of biocenosis}

Following the Pagán et al. (2017) method and using ArcGIS tool, the surfaces of the marine phanerogamy were obtained before and after San Juan nourishment (1990-1992). In Guardamar we have relied on the work done by Pagán et al. (2017) in the same area of study. Data were obtained from the campaign of November 1989, "Estudio Geofisico Marino de Alicante", and from a 1990 map of the beaches of San Juan and Muchavista (provided by the Institute of Marine Sciences, University of Alicante to scale 1:1000) in which the situation of the Posidonia oceanica meadow is available. The 1989 data col- lection equipment consisted of a Maxiran radio positioning system, with frequency band from 420 to $450 \mathrm{MHz}$ for bathymetry and a Klein side-beam pulse sonar with frequencies of $100 \mathrm{kHz}$ for morphology. The 2006 campaign is the Ecocartographic Study of the Provinces of Alicante and Valencia, (Ecolevante, 2006) whose objective was to have a complete knowledge of the entire Mediterranean coast. A multibeam probe system, wave compensator, gyroscopic, sound velocity meter, satellite corrected differential GPS and other auxiliary elements were used to carry it out.

\subsection{Sedimentology study}

For this study, it was necessary to be able to simulate the behaviour that sand particles suffer in the beach breakwater area, and its influence on the possible dissolution of carbonates, as well as on the decrease in $\mathrm{D}_{50}$ of the sample. The accelerated particle wear test proposed by López et al. (2016a) was used for this purpose. In this test, $75 \mathrm{~g}$ of beach sand sample and $500 \mathrm{ml}$ of seawater from the study area were poured into a magnetic stirrer at $1600 \mathrm{rpm}$ in 24-hour cycles. After each test cycle, sand sample granulometry (UNE 103101:1995, UNE 7050-2 and UNE 103100) and water calcimetry were performed using Bernard's calcimeter method (UNE 103200-93).

Scanning Electron Microscopy (SEM) was used to perform an elemental and morphological analysis of sediments. This technique allows us to obtain images of the sample, as well as its elementary composition and possible changes (Melgarejo et al., 2010). Thus, the microstructure and morphology of particles with their possible fracture faces and heterogeneity can be known. For the preparation of the SEM samples, clean grease and moisture-free particles were placed in the circular surface sample holder using carbon tape to bond them. It has not been necessary to cover them with a metal film (gold sputtering generally), since the equipment has the variable pressure working mode for observation of non-conductive samples.

Images obtained under the scanning electron microscope correspond to secondary electrons or backscattered electrons emitted after interaction with the sample of an incident beam of between 5 and $30 \mathrm{kV}$. The equipment is of the Hitachi brand S3000N model with thermoionic electron gun, has a Bruker X-ray detector model XFlash 3001 for microanalysis (EDS) and mapping. X-rays generated in a sample under electronic bombardment make it possible to identify the elements present and establish their concentration. This technique was carried out before the magnetic stirrer test. 
In order to determine the mineralogical composition of the sand samples, and thus to know the mineralogical phases present in the different sands studied, a Bruker D8-Advance diffractometer with Göebel mirror was obtained by means of XRD for the analysis of powder samples. The samples were ground in a ball mill at a size of $<0.063 \mathrm{~mm}$ and the analysis was performed at an acceleration voltage of $40 \mathrm{Kv}$ and $40 \mathrm{~mA}$ current. The angular sweep (2-Theta) on all samples was 4 to $60^{\circ}$.

A Rietveld analysis was performed with PANalytical Highscore Plus 4.6 software to quantify the phases present in the samples. The background was manually adjusted; the scaling factor, cell parameters and peak parameter were refined.

\section{Results and discussion}

Following the proposed methodology, shoreline evolution was obtained, taking into account that beach nourishment were carried out in both San Juan and Guardamar during the period analysed (Table 1). Based on this data and in view of these results, a different behaviour was observed in the shoreline evolution. According to Fig. 2, after the nourishment of San Juan and the consequent change in sediment typology, the loss of surface area in the period 1992-2017 was $13,121 \mathrm{~m}^{2}(3 \%)$, while the loss in the previous period (1956-1990) was $114,801 \mathrm{~m}^{2}(50 \%)$. However, in Guardamar the loss in 1992-2017 is $101,189 \mathrm{~m}^{2}(18 \%)$, and in the previous period it was $79,406 \mathrm{~m}^{2}$ (14\%). This small difference in Guardamar may be due to the cut of the longitudinal transport of the beaches north of Viveros, as a consequence of the construction of the jetty made at the mouth of the Segura River in 1990 (Pagán et al., 2017). However, if both beaches are analysed longitudinally, it is observed that in the northernmost beaches (Viveros and Babilonia), the loss of surface area is $46 \%$ and $89 \%$ respectively, while the southernmost beaches are the least affected, with an average loss of $7.36 \%$ (Fig. 2). In San Juan, after nourishment, the average surface area is very similar in all its length (San Juan and Muchavista) in the period analysed.

As can be seen in Table 2, the beach widths on both beaches between the different periods studied are statistically different (the results of Tukey's HSD analysis can be seen in supplementary material 2). Prior to the 1990-1991 actions, Guardamar and San Juan showed similar behaviour between them. However, after the interventions Guardamar continues to behave in a similar way, while San Juan behaves completely differently from the previous period (Table 2). When analysing erosion rates, the statistics indicate that Guardamar's behaviour is similar in both periods, although it is observed that Guardamar goes from being practically stable in the first period (LRRR $0.01 \mathrm{~m} / \mathrm{yr}$ ) to an erosion state with an LRR of $-0.18 \mathrm{~m} / \mathrm{yr}$. However, in San Juan, the opposite occurs; it goes from a strong erosion (LRR of $-0.87 \mathrm{~m} / \mathrm{yr}$ ) to a certain stability even with surface gain (LRRR of $0.22 \mathrm{~m} / \mathrm{yr}$ ), being the behaviour in both periods statistically different (p-value $<0.05$ ).

Likewise, on many beaches the wave affects the dune-beach system (Dissanayake et al., 2015), as is the case of Guardamar (Fig. 3a). As noted by Pagán et al. (2017) in the same study area, this important surface decrease in the northern zone could have been greater if the swell had not encountered obstacles such as: the dune at Viveros beach or the houses within the Maritime Terrestrial Public Domain

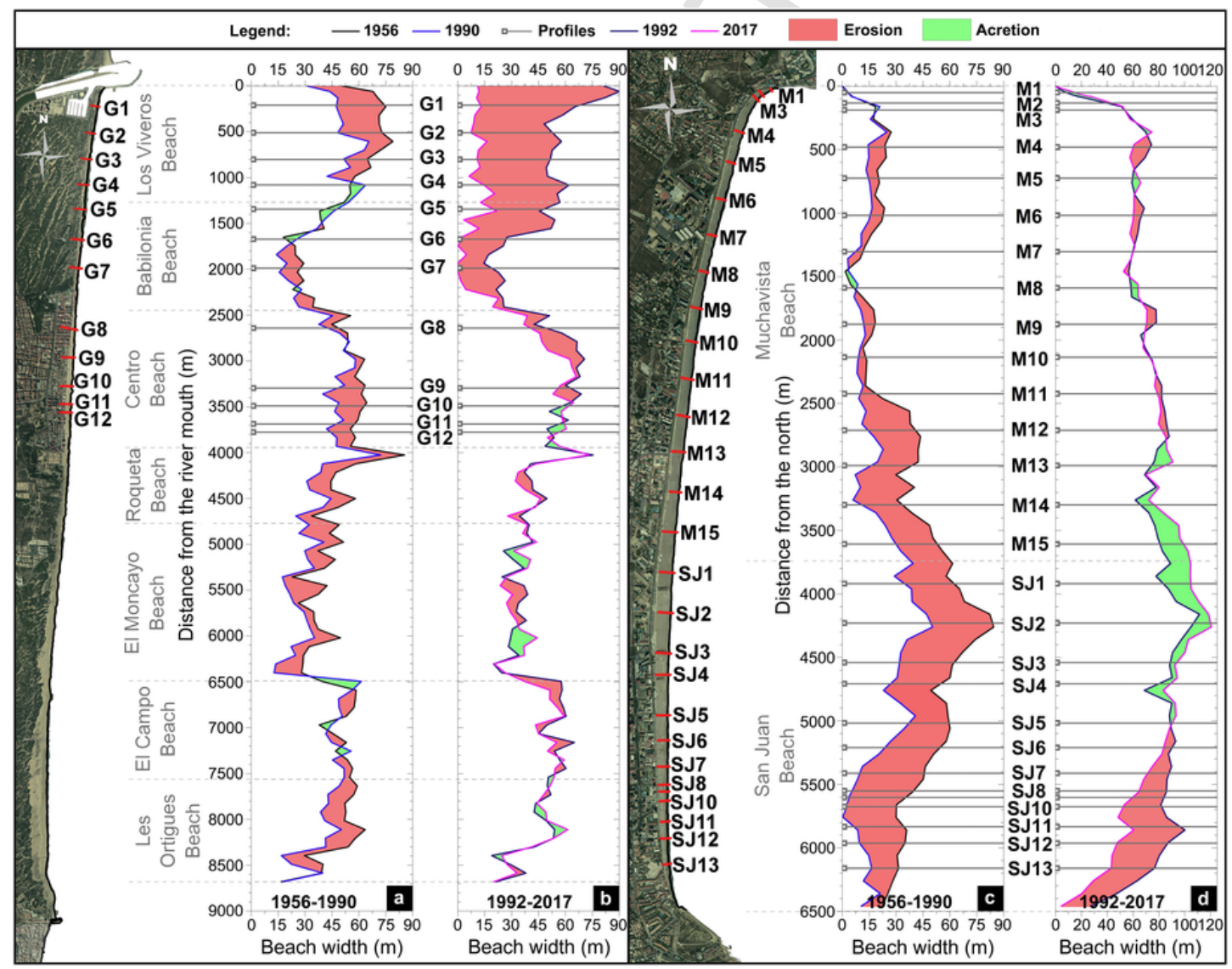

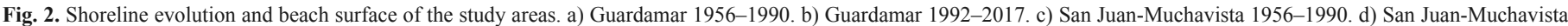
1992-2017. 
Table 2

Statistical description of the evolution of the shoreline in the studied periods. LRR is the linear regression rate of change, EPR is the end point rate, and NSM is the net shoreline movement. Positive EPR and LRR values represent shoreline movement toward the sea (rate of accretion), whereas negative values represent erosion. Different letters $(\mathrm{a}, \mathrm{b}, \mathrm{c})$ in the same column indicate statistical differences ( $\mathrm{p}$-value $<0.05$ ).

\begin{tabular}{llllllll}
\hline & Period & $\begin{array}{l}\text { Average } \\
\text { width }(\mathrm{m})\end{array}$ & $\begin{array}{l}\text { LRR } \\
(\mathrm{m} / \mathrm{yr})\end{array}$ & $\mathrm{R}^{2}$ & $\begin{array}{l}\text { EPR } \\
(\mathrm{m} / \mathrm{yr})\end{array}$ & $\begin{array}{l}\text { NSM } \\
(\mathrm{m})\end{array}$ & NSM \\
\hline \multirow{2}{*}{ Guardamar } & $1956-1990$ & $56.4 \pm 6.3^{\mathrm{ab}}$ & $0.01^{\mathrm{a}}$ & 0.0001 & -0.15 & -5 & $-8 \%$ \\
& $1992-2017$ & $67.6 \pm 5.8^{\mathrm{a}}$ & $-0.18^{\mathrm{a}}$ & 0.0629 & -0.33 & -8 & $-12 \%$ \\
San Juan & $1956-1990$ & $46.6 \pm 16.5^{\mathrm{b}}$ & $-0.87^{\mathrm{b}}$ & 0.3695 & -1.12 & -38 & $-51.3 \%$ \\
& $1992-2017$ & $103.0 \pm 4.9^{\mathrm{c}}$ & $0.22^{\mathrm{c}}$ & 0.1300 & 0.22 & 5 & $5.5 \%$ \\
\hline
\end{tabular}

(MTPD) in Babylon. Anthropic modifications may also occur, as can be seen in San Juan (Fig. 3c) the loss is distributed throughout the entire beach, although in some areas it is observed how the material accumulates the intermediate zone of the beach, possibly due to the existence of palm trees. For this reason, for the real analysis of sediment loss, cross-shore profiles were taken on both beaches in order to measure the volume of sand lost between the periods 2009-2017. From the results (Fig. 3), it can be see that Guardamar has lost $93,659 \mathrm{~m}^{3}$ and San Juan $60,816 \mathrm{~m}^{3}$ of sand. From the analysis of both volumes is known: i) in Guardamar the lost volume, as well as its surface, is produced mainly on the beaches of Viveros and Babilonia; ii) in San Juan it is possible that part of that lost volume has been artificially poured to maintain the beach surface. All this data is providing information that requires a thorough analysis of the causes of this different evolution, in order to ensure that future nourishments be more stable over time.

According to several authors, one of the main factors influencing the shoreline evolution is wave energy (Bakhtyar et al., 2009; Yoshikawa and Nemoto, 2010). San Juan and Guardamar are beaches that have a similar orientation $\left(96.1^{\circ} \mathrm{N}\right.$ Guardamar and $94.5^{\circ} \mathrm{N}$ San Juan). However, the small difference between mean flow and Guardamar orientation $\left(94.9^{\circ} \mathrm{MF} v s .96 .1^{\circ}\right.$ orientation), according to Pagán et al. (2018), generates a certain tendency to rotate becoming perpendicular to the mean flow. Therefore, as shown in Fig. 2, the southernmost zone of Guardamar has a certain stability on its surface (thanks to the longitudinal transport) and yet in San Juan the highest rates of erosion (although small) are found near Huertas Cape, due to the currents produced by the diffraction of the waves in it. Therefore, it can be said that the swell produces a generally cross-shore sediment transport. If observed, the wave heights, periods and mean flow of both beaches are similar (Table 3), but the evolution of their surface is different. This is why, although energy is a determining factor in the erosion of the particles that make up the beach sand (López et al., 2016b), it does not influence the evolution of both beaches in the same way, nor between periods (as is the case of San Juan beach).

One factor related to the energy entering the beach is the presence of Posidonia oceanica meadows. On one hand it reduces the energy entering the beach, and on the other hand it stabilizes the profile, as a consequence of the density beams, stem height and the depth at which it is situated (Aragonés et al., 2017a; Koftis and Prinos, 2011; Prinos et al., 2010). In addition, its burial due to the beach nourishments can destabilize the profile causing great retreats of the shoreline (Aragonés et al., 2015; Pagán et al., 2016). Therefore, it is necessary to take into account whether the posidonia surface has changed and the transverse profile of the area studied before and after nourishment. Fig. 4 shows that in San Juan (the only area with Posidonia oceanica) the surface in both periods has not changed. And in Guardamar according to the studies carried out by Pagán et al. (2017) it is noted that there has been an increase in the area of plant species between 1989 and 2006 from only two species in 1989 to six in 2006. However, an increase of approximately $1 \mathrm{~m}$ in depth has been detected in the area around the mouth of the Segura River (Viveros beach) between those same years. The beach surface lost due to the lowering of the seabed has been estimated using the equilibrium profile method proposed by Aragonés et al. (2016b) with a value of approximately $51.4 \%$ (Fig. 5). Regarding the analysis of the cross-shore profile on both beaches, the 1992-2017 period has been studied in order to achieve this, the depth of closure has been obtained from the method proposed by Aragonés et al. (2017b). The results show that the DoC is very similar on both beaches with values of $-5.6 /-5.3 \mathrm{~m}$ and with slopes of $0.0135 / 0.0141$ in San Juan and $-5.03 \mathrm{~m}$ and

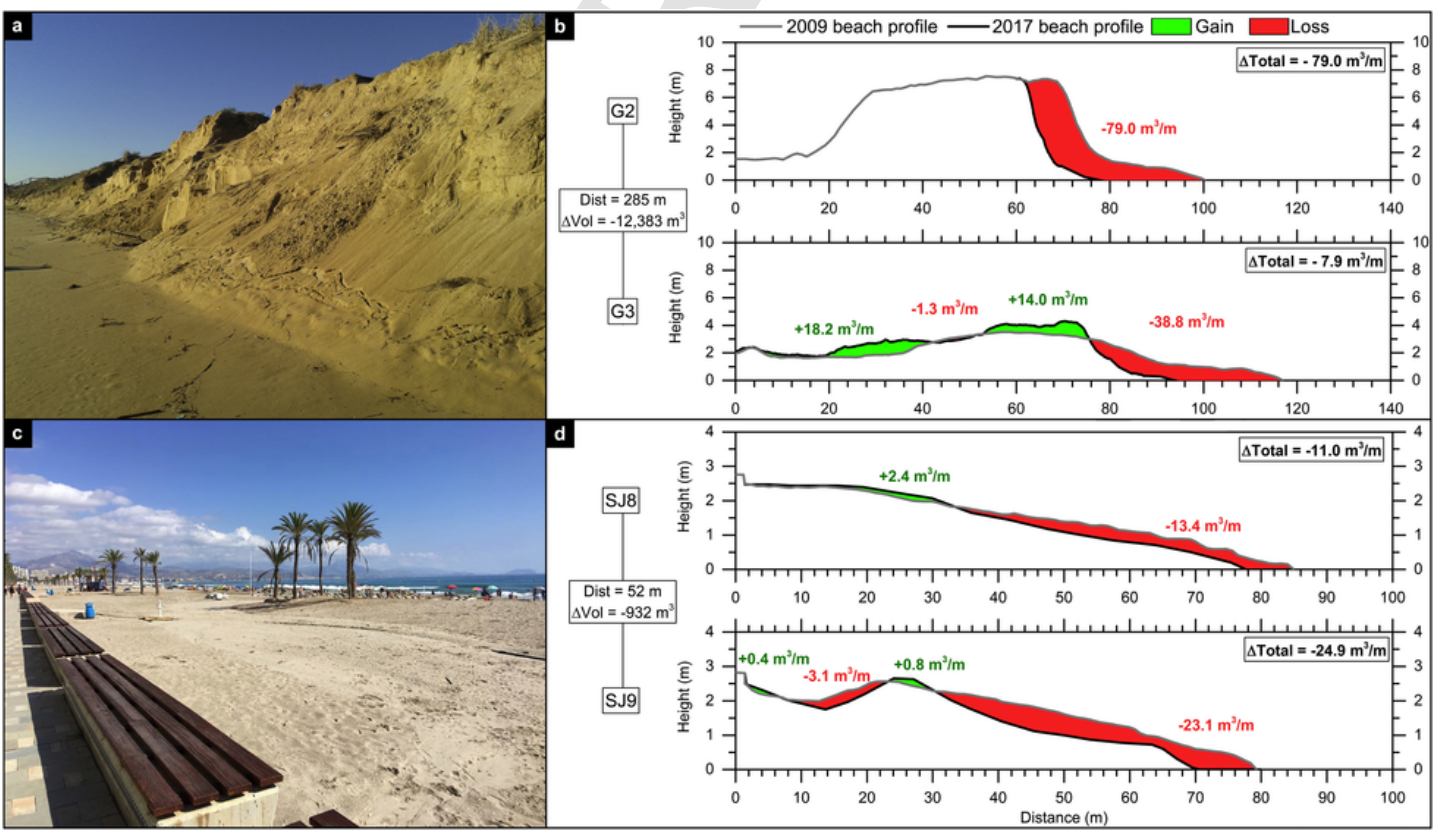

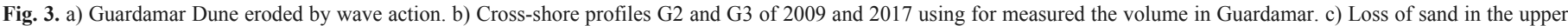
part of the beach, exposing the roots of the palm trees. d) Cross-shore profiles SJ8 and SJ9 of 2009 and 2017 using for measured the volume in San Juan-Muchavista. 
Table 3

Wave heights, periods corresponding to the mean flow (MF) in deep water and the depth of closure (DoC) for each of the study periods.

\begin{tabular}{|c|c|c|c|c|c|}
\hline & & San Juan & & Guardamar & \\
\hline & & 1956-1990 & 1992-2017 & 1956-1990 & 1992-2017 \\
\hline \multirow[t]{3}{*}{ Deep water } & $\operatorname{MF}\left({ }^{\circ}\right)$ & 96.2 & 95.8 & 90.9 & 93.0 \\
\hline & $\mathrm{H}_{\mathrm{s}, 12}(\mathrm{~m})$ & 2.20 & 2.20 & 2.40 & 2.17 \\
\hline & $\mathrm{T}_{\mathrm{p}}(\mathrm{s})$ & 9.6 & 10.2 & 9.0 & 8.7 \\
\hline \multirow[t]{3}{*}{ DoC } & $\operatorname{MF}\left({ }^{\circ}\right)$ & 95.3 & 94.9 & 93.5 & 94.2 \\
\hline & $\mathrm{H}_{\mathrm{s}, 12}(\mathrm{~m})$ & 2.50 & 2.56 & 2.78 & 2.52 \\
\hline & $\mathrm{T}_{\mathrm{p}}(\mathrm{s})$ & 10.3 & 10.9 & 10.1 & 9.8 \\
\hline
\end{tabular}

0.0137 of slope in Guardamar, which confirms the previously indicated that the incident energy is practically the same on both beaches (Fig. 4).

When coastal engineers calculate the volume needed for a beach nourishment, they usually use the equilibrium profile which, according to various authors, depends on the energy, sediment fall velocity, $\mathrm{D}_{50}$ or specific gravity of the sediment (Dean, 1991; Romańczyk et al., 2005). However, in this study, when analysing the energy it is observed that this is similar in both beaches, and also when analysing the sediment it is observed that its median sediment size is similar $(0.249 \mathrm{~mm}$ in Guardamar vs. $0.220 \mathrm{~mm}$ in San Juan, Fig. 6), so what differences justify the different shoreline evolution in both beaches?

The studies carried out on sediment wear by López et al. (2016a) show that two sand samples with similar sizes can decrease in size differently from accelerated particle wear testing. These authors conclude that particle shock, carbonate dissolution and particle separation are the causes of this size decrease. Fig. 6 shows that in the case of Guardamar the sediment sample becomes smaller than $0.063 \mathrm{~mm}$ in just 3 cycles, while the San Juan sample takes 5 cycles. In reality and within the study area (Guardamar) Aragonés et al. (2016a) concluded that this particle size $(<0.063 \mathrm{~mm})$ has a tendency to move, through gravitational movements, toward the abyssal plains, which may explain the disappearance of part of the lost volumes of sand. In addition, the Guardamar sample has the highest weight and $\mathrm{D}_{50}$ losses per cycle. Probably one of the factors that makes Guardamar reduce its size more quickly is the dissolution of carbonates. Indeed, if Guardamar and San Juan (Fig. 6) are analysed on their cycle,
Guardamar loses 3 times more carbonates than San Juan $(0.93 \%$ Guardamar and $0.30 \%$, San Juan). This may be due to the different mineralogy (Fig. 7), the beach of Guardamar presents mainly quartz $(30 \%)$, calcite $(38.2 \%)$, and dolomite $(29.6 \%)$, while the beach of San Juan presents mainly quartz (62.5\%) and calcite (35.5\%).

As Guardamar is the beach with the greatest loss of surface area and volume, a mineralogical study by fractions (Table 4) was carried out. This shows that: i) initially the large fractions are the ones with the highest percentages of calcite and in the intermediate fractions the highest dolomite content is found, maintaining a stable quartz content throughout the distribution of sizes; ii) after accelerated particle wear test, an increase in the proportion of quartz is observed. This would indicate the possible continuous wear of the carbonate fraction (calcite and dolomite). In the finer fractions $(0.063-0.125 \mathrm{~mm})$ it is observed that calcite is the mineral that wears less after the accelerated test of wear (see the increase in its percentage in Table 4) that could explain the dissolution of carbonates, which is observed in the test as increasing to $4.88 \% \mathrm{CaCO}_{3}$ in the last cycle.

Another factor, perhaps more important, is the morphological study of both sand samples. The microscopy shows that Guardamar particles present angular shapes at the edges of the particles, foliation planes, and large number of cracks in the particles. In contrast, in San Juan the particles have rounded shapes, are homogeneous and without such a clear presence of cracks in the grains and, although some particles are observed formed by a conglomerate grains of minerals, these are the minimum of the sample (Fig. 8). Indeed, in the studies carried out by Chiva et al. (2018) or Pagán et al. (2018) is observed as this type of conglomerates or grains that make up the sediment and that present weak fractures or joints in which particles are formed between different particles of the same grain, are the fundamental factors in the wear of the sediments. This could explain the worst behaviour of one sand against another.

As the source of dredging in San Juan is the same as in the study carried out by Pagán et al. (2018) (Sierra Helada), the results of the accelerated wear test of all beaches have been compared. From its comparison (Fig. 9) it is observed that its behaviour in the magnetic accelerator is very similar to Carrer de mar beach, being the one that behaves worst of the other 2 beaches analysed by Pagán et al. (2018) (Centro of Villajoyosa, and Arenal of Calpe). Therefore, one might think that if San Juan beach had been nourished with sand similar to

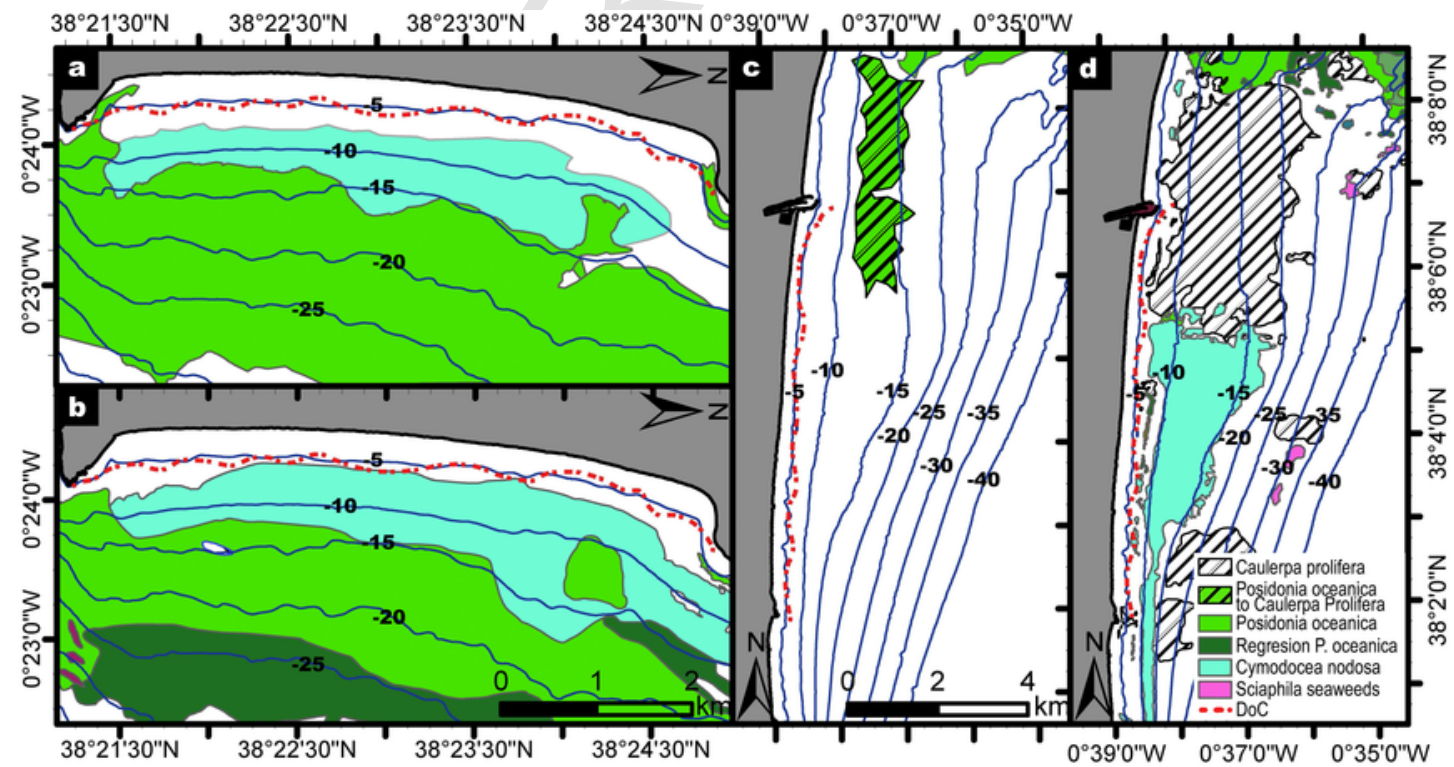

Fig. 4. Evolution of marine vegetation between 1989 and 2006 and position of the depth of closure. a) San Juan 1989. b) San Juan 2006. c) Guardamar 1989. d) Guardamar 2006. 


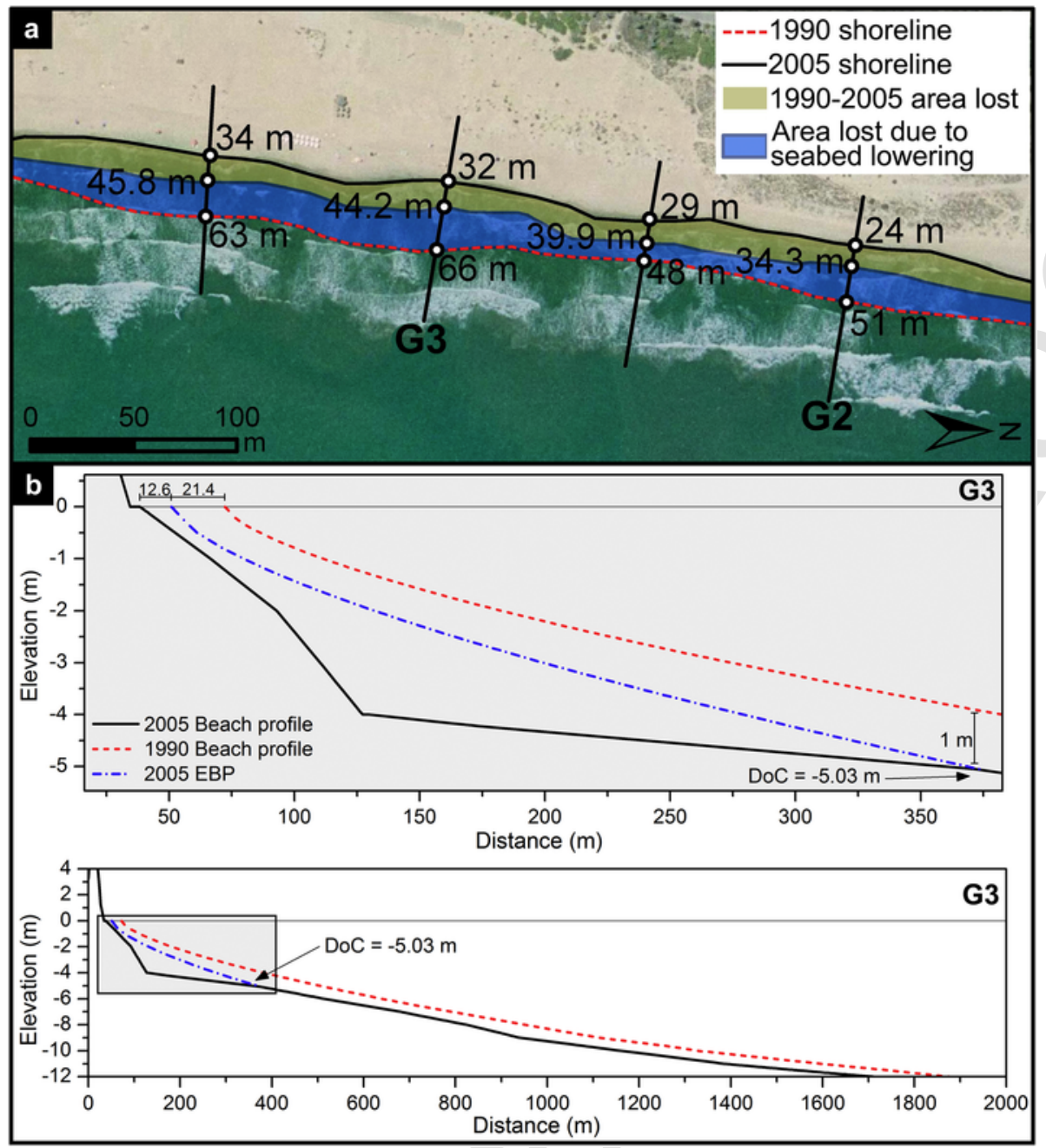

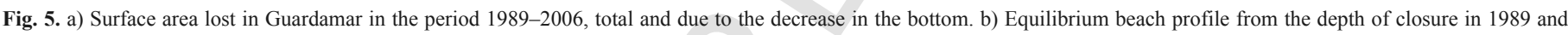
2006 at Guardamar.

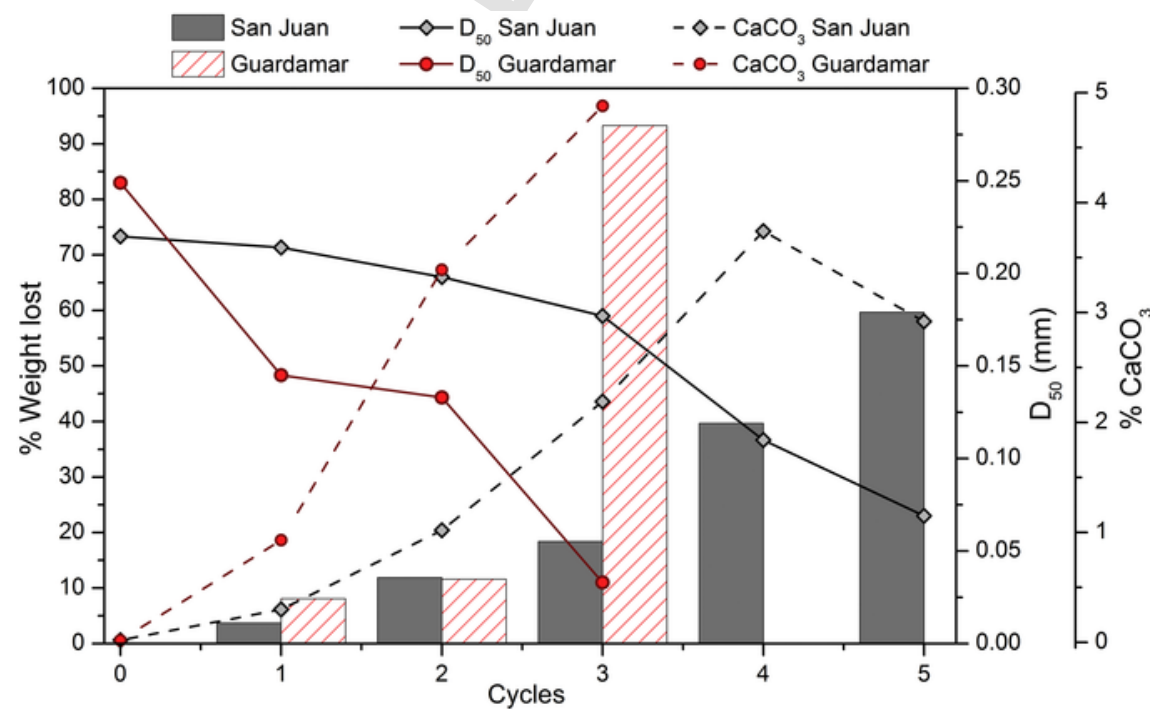

Fig. 6. Evolution of the median sediment size, weight loss and $\mathrm{CaCO}_{3}$ during the accelerated particle wear test on the beaches of San Juan and Guardamar. 


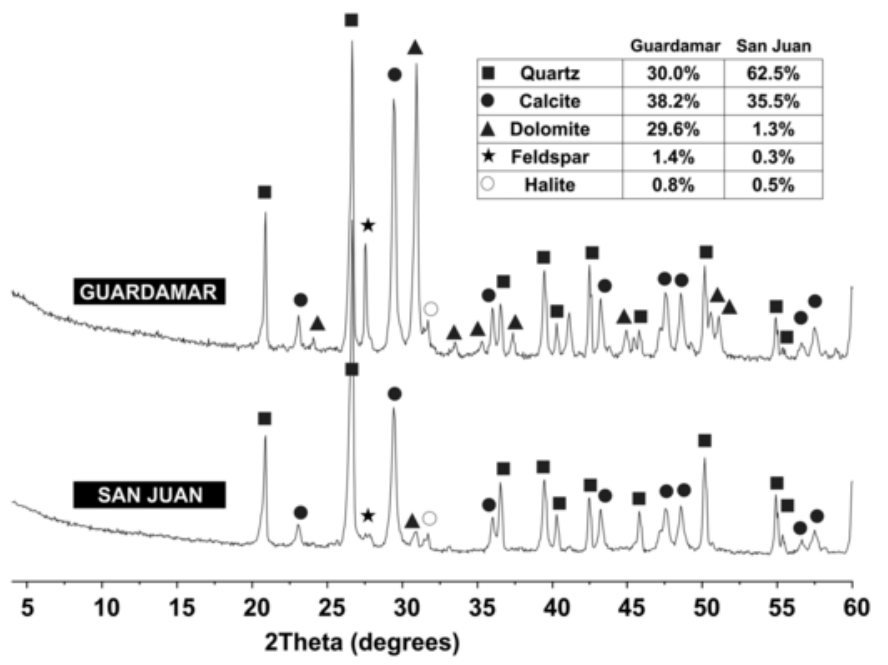

Fig. 7. DRX from the beaches of Guardamar and San Juan.

Table 4

Mineralogical composition of each of the fractions of sediment samples analysed from Guardamar beach, before and after submitting them to the accelerated particle weathering test.

\begin{tabular}{lllll}
\hline \multicolumn{5}{c}{ Particles size (mm) } \\
\hline \multirow{5}{*}{ Before testing } & Quartz (\%) & 32.7 & 30.3 & 36.7 \\
& Calcite (\%) & 30.1 & 25 & 46.1 \\
& Dolomite (\%) & 36.5 & 43.7 & 16.7 \\
\multirow{5}{*}{ After testing } & $0.125-0.200$ & $0.200-0.250$ \\
& Feldspar (\%) & 0.6 & 0.9 & 0.5 \\
& Quartz (\%) & 29.7 & 58 & 49 \\
& Calcite (\%) & 40.5 & 21.5 & 28.2 \\
& Dolomite (\%) & 29.3 & 19.4 & 22.3 \\
& Feldspar (\%) & 0.5 & 1.2 & 0.6 \\
\hline
\end{tabular}

the Centro beach (Villajoyosa), its behaviour would have been even better than the current one.

Last but not least important is the comparative analysis of the San Juan samples before and after beach nourishment (1991). Table 4 shows that the original sample of the beach had $73.6 \%$ of calcite and
$26.4 \%$ of quartz (Serra, 1988), while the current sand has $35.5 \%$ of calcite and $62.5 \%$ of quartz. The great difference in the evolution of the coastline in both periods studied together with the different mineralogy indicates that: i) possibly, there was a greater proportion of dissolution of the carbonates. ii) Although morphological data are not available, it is possible that there were many of the particles that formed the sample, formed by weak unions, which made San Juan erode more quickly in the first period studied.

Therefore, this study shows the importance of the morphology and mineralogy of the particle that composes the sand sample, in coastal erosion. For this reason, sedimentary studies are necessary to search the optimum sand for a nourishment, which will be directly related to the duration or maintenance of the shoreline.

\section{Conclusion}

In order to justify the different behaviour of the coastline of two very similar beaches in terms of their grain size and orientation, all the natural factors affecting the beaches studied have been analysed. From the study of energy (wave height, period, etc.), its biocenosis, transverse profile, lost volume, and sediment (morphology and mineralogy), it is concluded that:

- Wave energy influences the degree of erosion of a beach. However, even though it is an important factor, it has been observed that when the energy incident on different beaches is similar, but the degree of erosion on both beaches is very different, there are other factors related to sediment (mineralogy or morphology) that clarify the different degree of erosion.

- That the presence of calcite in mineralogy can be one of the key factors in erosion. This is demonstrated in the variation of the erosion rate that San Juan beach suffers before and after nourishment, possibly because of the increase of $\mathrm{CO}_{2}$ in the atmosphere.

- Sediment morphology can be the most important factor in the erosion of the shoreline.

Because of this study, the need to include accelerated wear testing of particles prior to the use of any sand in a regeneration is clear. Although a significant amount of data on coastal erosion is currently available, research needs to be carried out on what kind of sands are in the world, so that an inventory can be made to analyse the risks in each area.
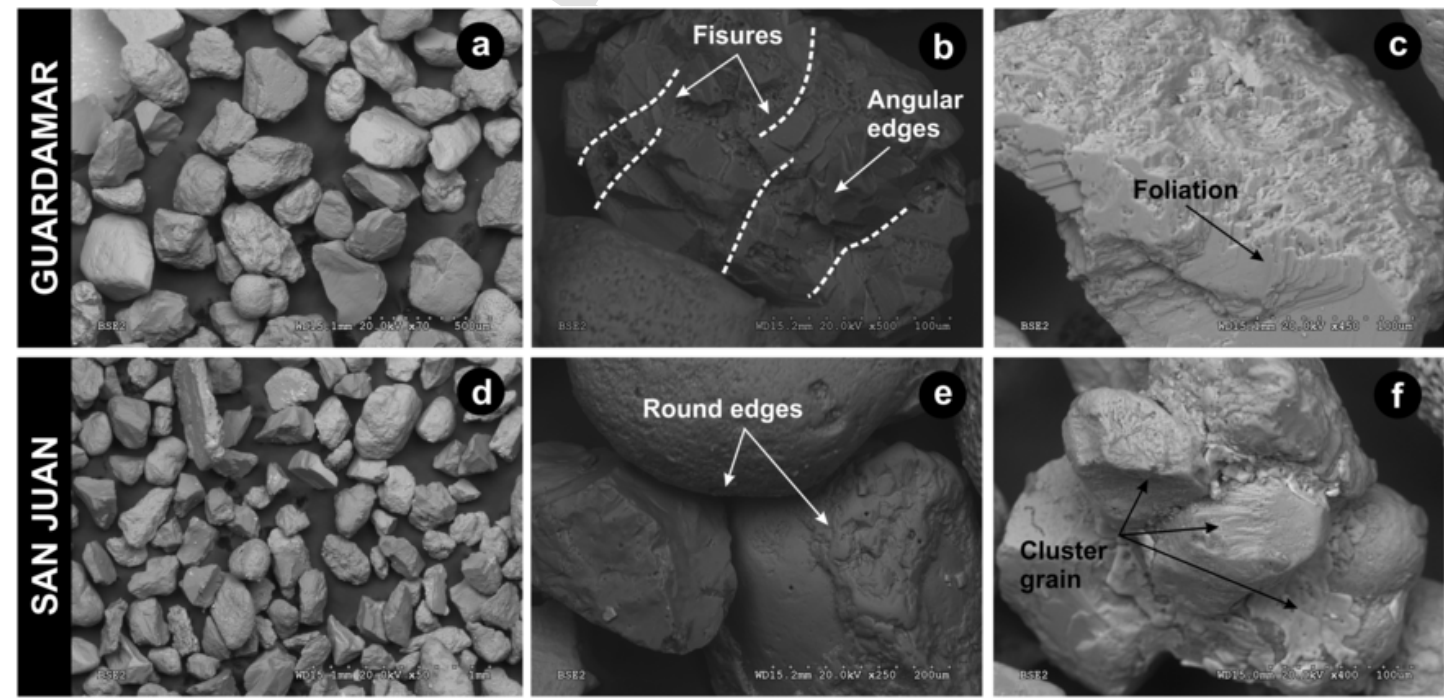

Fig. 8. Morphology of the particles of Guardamar (a, b and c) and San Juan (d, e and f). 


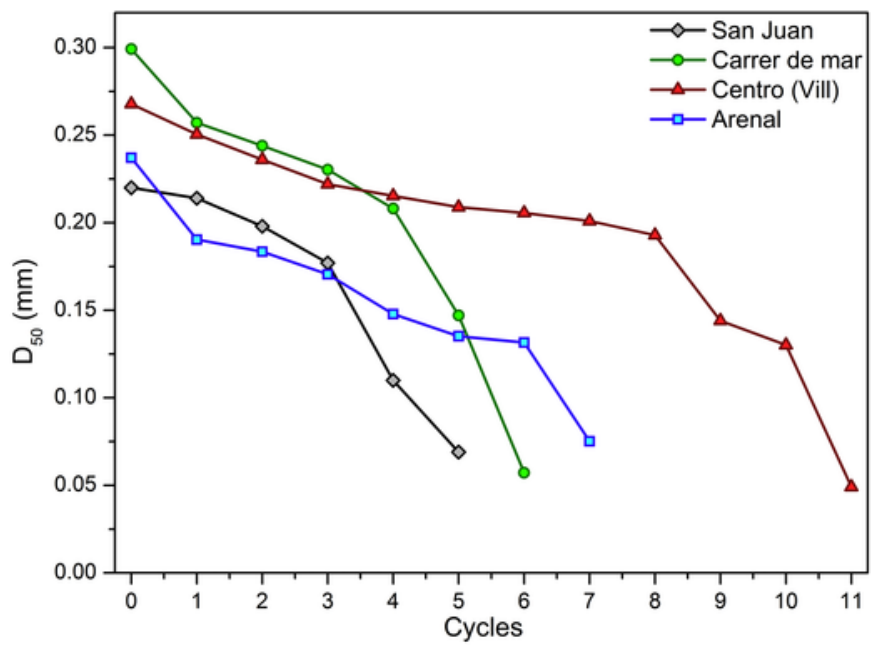

Fig. 9. Evolution of the average size during the accelerated particle wear test on the beaches of San Juan, Carrer de mar, Centro of Villajoyosa and Arenal of Calpe.

\section{Acknowledgements}

Authors thank Dirección General de Costas (Ministerio de Agricultura y Medio Ambiente) and Puertos del Estado for providing access to their data.

This work was partially supported by the Universidad de Alicante through the project "Estudio sobre el desgaste y composición de los sedimentos y su influencia en la erosión de las playas españolas" (GRE16-09).

\section{Appendix A. Supplementary data}

Supplementary data to this article can be found online at https:// doi.org/10.1016/j.scitotenv.2018.04.037.

\section{References}

Anders, F.J., Byrness, M.R., 1991. Accuracy of shoreline change rates as determined from maps an aerial photographs. Shore Beach 59, 17-26.

Anthony, E.J., 2015. Wave influence in the construction, shaping and destruction of river deltas: a review. Mar. Geol. 361, 53-78.

Anthony, E.J., Marriner, N., Morhange, C., 2014. Human influence and the changing geomorphology of Mediterranean deltas and coasts over the last 6000 years: from progradation to destruction phase?. Earth Sci. Rev. 139, 336-361.

Aragonés, L., García-Barba, J., García-Bleda, E., López, I., Serra, J.C., 2015. Beach nourishment impact on Posidonia oceanica: case study of Poniente Beach (Benidorm, Spain). Ocean Eng. 107, 1-12.

Aragonés, L., Pagán, J.I., López, M.P., García-Barba, J., 2016. The impacts of Segura River (Spain) channelization on the coastal seabed. Sci. Total Environ. 543 , 493-504.

Aragonés, L., Serra, J.C., Villacampa, Y., Saval, J.M., Tinoco, H., 2016. New methodology for describing the equilibrium beach profile applied to the Valencia's beaches. Geomorphology 259, 1-11.

Aragonés, L., López, I., Villacampa, Y., Navarro-González, F.J., 2017. Using the presence of seagrass Posidonia oceanica to model the equilibrium profile parameter A of sandy beaches in Spain. J. Coast. Res. 33, 1074-1085.

Aragonés, L., Pagán, J.I., López, I., Serra, J.C., 2017. Depth of closure: new calculation method based on sediment data. Int. J. Sediment Res.(In press).

Baily, B., Nowell, D., 1996. Techniques for monitoring coastal change: a review and case study. Ocean Coast. Manag. 32, 85-95.

Bakhtyar, R., Barry, D.A., Li, L., Jeng, D.S., Yeganeh-Bakhtiary, A., 2009. Modeling sediment transport in the swash zone: a review. Ocean Eng. 36, 767-783.

Ballesteros, C., Jiménez, J.A., Valdemoro, H.I., Bosom, E., 2018. Erosion consequences on beach functions along the Maresme coast (NW Mediterranean, Spain). Nat. Hazards 90, 173-195.
Bayram, A., Larson, M., Miller, H.C., Kraus, N.C., 2001. Cross-shore distribution of longshore sediment transport: comparison between predictive formulas and field measurements. Coast. Eng. 44, 79-99.

Bui, E.N., Mazzullo, J.M., Wilding, L.P., 1989. Using quartz grain size and shape analysis to distinguish between aeolian and fluvial deposits in the Dallol Bosso of Niger (West Africa). Earth Surf. Process. Landf. 14, 157-166.

Chiva, L., Pagán, J.I., López, I., Tenza-Abril, A.J., Aragonés, L., Sánchez, I., 2018. The effects of sediment used in beach nourishment: study case El Portet de Moraira beach. Sci. Total Environ. 628-629, 64-73.

De Leo, F., Besio, G., Zolezzi, G., Bezzi, M., Floqi, T., Lami, I., 2017. Coastal erosion triggered by political and socio-economical abrupt changes: the case of Lalzit Bay, Albania. Coast. Eng. Proc. 1, 13.

Dean, R.G., 1991. Equilibrium beach profiles: characteristics and applications. J. Coast. Res. 7, 53-84.

Demarest, J.M., Kraft, J.C., 1987. Stratigraphic record of quaternary sea Levels: implications for more Ancient Strata. In: Nummedal, D., Pilkey, O.H., Howard, J.D. (Eds.), Sea-Level Fluctuation and Coastal Evolution. SEPM Society for Sedimentary Geology.

Dissanayake, P., Brown, J., Wisse, P., Karunarathna, H., 2015. Effects of storm clustering on beach/dune evolution. Mar. Geol. 370, 63-75.

EC EuropeanCommission, 2004. Part I-Major Findings and Policy Recommendations of the EUROSION Project. Living With Coastal Erosion in Europe: Sediment and Space for Sustainability. Official Publications of the European Communities, Luxembourg, 57.

Ecolevante, 2006. Estudio ecocartográfico del litoral de las provincias de Alicante y Valencia. Dirección General de Costas, Ministerio de Medio Ambiente, Spain (Available online). http://www.mapama.gob.es/es/costas/temas/ proteccion-costa/ecocartografias/ecocartografia-alicante.aspx.

EEA EropeanEnvironmentalAgency, 2006. The Changing Faces of Europe's Coastal Areas. Report No 6/2006. Eropean Environmental Agency, Copenhagen, 112.

Emery, K.O., 1961. A simple method of measuring beach profiles. Limnol. Oceanogr. $6,90-93$.

Fenster, M.S., Dolan, R., Elder, J.F., 1993. A new method for predicting shoreline positions from historical data. J. Coast. Res. 9, 147-171.

Guillén, J., Hoekstra, P., 1996. The "equilibrium" distribution of grain size fractions and its implications for cross-shore sediment transport: a conceptual model. Mar. Geol. 135, 15-33.

Hallermeier, R.J., 1978. In: Engineers, ASoC (Ed.), Uses for a Calculated Limit Depth to Beach Erosion. 16th International Conference on Coastal Engineering. American Society of Civil Engineers (ASCE), Hamburg, Germany, pp. 1493-1512.

Hallermeier, R.J., 1980. A profile zonation for seasonal sand beaches from wave climate. Coast. Eng. 4, 253-277.

Infantes, E., Terrados, J., Orfila, A., Cañellas, B., Álvarez-Ellacuria, A., 2009. Wave energy and the upper depth limit distribution of Posidonia oceanica. Bot. Mar. 52, 419-427.

Jiménez, J.A., Sánchez-Arcilla, A., Bou, J., Ortiz, M.A., 1997. Ocean \& Coastal Management. J. Coast. Res. 13, 1256-1266.

Koftis, T., Prinos, P., 2011. Estimation of Wave Attenuation Over Posidonia oceanica. 5th International Short Conference on Applied Coastal Research, Aachen, Germany. 264-271.

Kumar, V.S., Pathak, K.C., Pednekar, P., Raju, N.S.N., Gowthaman, R., 2006. Coastal processes along the Indian coastline. Curr. Sci. 91, 530-536.

López, I., López, M., Aragonés, L., García-Barba, J., López, M.P., Sánchez, I., 2016. The erosion of the beaches on the coast of Alicante: study of the mechanisms of weathering by accelerated laboratory tests. Sci. Total Environ. 566-567, 191-204.

López, M., López, I., Aragonés, L., Serra, J.C., Esteban, V., 2016. The erosion on the east coast of Spain: wear of particles, mineral composition, carbonates and Posidonia oceanica. Sci. Total Environ. 572, 487-497.

Marchand, M., 2010. Concepts and Science for Coastal Erosion Management. Concise Report for Policy Makers, Deltares, Delf. 32.

Marcomini, S.C., López, R.A., 1997. Influencia de la urbanización en la dinámica costera, Villa Gesell, provincia de Buenos Aires, República Argentina. Rev. Asoc. Argent. Sedimentología 4, 79-96.

Melgarejo, J.C., Proenza, J.A., Galí, S., Llovet, X., 2010. Técnicas de caracterización mineral y su aplicación en exploración y explotación minera. Bol. Soc. Geol. Mex. $62,1-23$.

Moore, L.J., Griggs, G.B., 2002. Long-term cliff retreat and erosion hotspots along the central shores of the Monterey Bay National Marine Sanctuary. Mar. Geol. 181, 265-283.

Newton, A., Carruthers, T.J.B., Icely, J., 2012. The coastal syndromes and hotspots on the coast. Estuar. Coast. Shelf Sci. 96, 39-47.

Norcross, Z.M., Fletcher, C.H., Merrifield, M., 2002. Annual and interannual changes on a reef-fringed pocket beach: Kailua Bay, Hawaii. Mar. Geol. 190, 553-580.

Nováčková, M., Tol, R.S.J., 2018. Effects of sea level rise on economy of the United States. J. Environ. Econ. Policy 7, 85-115.

Ojeda, J., Borgniet, L., Pérez, A.M., Loder, J.F., 2002. Monitoring morphological changes along the coast of Huelva (SW Spain) using soft-copy photogrammetry and GIS. J. Coast. Conserv. 8, 69-76. 
Ojeda, J., Díaz, M.P., Prieto, A., Álvarez, J., 2013. Línea de costa y sistemas de información geográfica: modelo de datos para la caracterización y cálculo de indicadores en la costa andaluza. Investig. Geográficas (60), 37-52.

Pagán, J.I., Aragonés, L., Tenza-Abril, A.J., Pallarés, P., 2016. The influence of anthropic actions on the evolution of an urban beach: case study of Marineta Cassiana beach, Spain. Sci. Total Environ. 559, 242-255.

Pagán, J.I., López, I., Aragonés, L., Garcia-Barba, J., 2017. The effects of the anthropic actions on the sandy beaches of Guardamar del Segura, Spain. Sci. Total Environ. 601-602, 1364-1377.

Pagán, J.I., López, M., López, I., Tenza-Abril, A.J., Aragonés, L., 2018. Study of the evolution of gravel beaches nourished with sand. Sci. Total Environ. 626, 87-95.

Pardo, J.E., Sanjaume, E., 2001. Análisis multiescalar de la evolución costera. Cuad. Geografía 69-70, 95-125.

Payo, A., Mukhopadhyay, A., Hazra, S., Ghosh, T., Ghosh, S., Brown, S., et al., 2016 Projected changes in area of the Sundarban mangrove forest in Bangladesh due to SLR by 2100. Clim. Chang. 139, 279-291.

Prinos, P., Stratigaki, V., Manca, E., Losada, I., López, J., Sclavo, M., et al., 2010. Wave Propagation Over Posidonia Oceanica: Large Scale Experiments. Proceedings of the 7th HYDRALAB III Joint Transnational Access User Meeting Hannover, Germany. 57-60.

Roberts, J., Jepsen, R., Gotthard, D., Lick, W., 1998. Effects of particle size and bulk density on erosion of quartz particles. J. Hydraul. Eng. 124, 1261-1267.
Romańczyk, W., Boczar-Karakiewicz, B., Bona, J.L., 2005. Extended equilibrium beach profiles. Coast. Eng. 52, 727-744

Serra, J.C., 1988. Procesos litorales de las costas de Castellón. Universidad Politécnica de Valencia. Department of Transport Infrastructure and Engineering. Masther's thesis. Universidad Politécnica de Valencia, Valencia, Spain, 890.

Spencer, T., Schuerch, M., Nicholls, R.J., Hinkel, J., Lincke, D., Vafeidis, A.T., et al., 2016. Global coastal wetland change under sea-level rise and related stresses: the DIVA wetland change model. Glob. Planet. Chang. 139, 15-30.

Syvitski, J.P.M., Saito, Y., 2007. Morphodynamics of deltas under the influence of humans. Glob. Planet. Chang. 57, 261-282.

Syvitski, J.P.M., Vörösmarty, C.J., Kettner, A.J., Green, P., 2005. Impact of humans on the flux of terrestrial sediment to the global coastal ocean. Science 308, 376-380.

Syvitski, J.P.M., Kettner, A.J., Overeem, I., Hutton, E.W.H., Hannon, M.T., Brakenridge, G.R., et al., 2009. Sinking deltas due to human activities. Nat. Geosci. 2, 681.

Yoshikawa, S., Nemoto, K., 2010. Seasonal variations of sediment transport to a canyon and coastal erosion along the Shimizu coast, Suruga Bay, Japan. Mar. Geol. 271, 165-176. 